\title{
THE READINESS OF FUTURE PRIMARY SCHOOL TEACHERS FOR TOLERANT EDUCATION OF STUDENTS: THE STRUCTURE, CRITERIA, INDICATORS
}

\section{Cherednyk Lidiya ${ }^{1}$}

DOI: https://doi.org/10.30525/978-9934-571-89-3_29

Problem statement. The readiness of future teachers to tolerate the education of primary school students is considered in the scientific and pedagogical literature as a kind of general professional qualification, therefore the leading way of determining the structure of this pedagogical phenomenon is the use of broader features in terms of the category, that is, professional readiness.

One of the approaches to determining the structure of future teachers' readiness for tolerant education of junior pupils is to follow the logic of building pedagogical activity. Since the teacher is a carrier (translator, founder, driving force, etc.) of the pedagogical system, its readiness must be measured by the ability to meet the requirements of each component of the teaching system.

According to Kondrashova L., the professional readiness of the future teacher to educate students is a multidimensional system that covers a number of components: motivational; orientational; cognitive-operational; emotionally-volitional; psychophysiological; evaluative.

O. Budnik represents the structure of the professional readiness of the future primary school teacher to social and pedagogical activity provide as inseparable unity of motivational, cognitive, social and communicative, activity-technological and moral-aesthetic components, and its criteria - ideological; motivational; emotional; cognitive; communicative and active [1].

Having analyzed the recent studies on the readiness of future teachers for tolerant education, I. Shcherbak concluded that the following main components are distinguished: motivational (axiological or value-motivational), which includes needs and motives; content-procedural (meaningful, cognitive-orientational or motivationalcognitive), which implies the presence of theoretical knowledge and understanding of the essence of a particular activity; projective-constructive (procedural, praxeological, operative, operative-operative or reflexive), which captures the necessary practical skills [5, p. 103-104].

${ }^{1}$ Berdiansk State Pedagogical University, Ukraine 
K. Rozum somewhat differently, groups three interrelated components in the structure of readiness of future teachers of the humanitarian direction to prevent and resolve conflicts in educational activities with students, having combined the cognitive sphere with the activity and having emphasized the behavious analysis: person-motivational, cognitive-active, behavioral and analytical [4].

K. Rozum considers the following criteria and indicators:

- inductive (the presence of positive motivation for pedagogical activity, success in resolving conflicts, tolerance);

- content-operational (awaraness of conflict types, the availability of organizational and communicative skills);

- regulatory-axiological (the ability to gain pedagogically relevant behaviour in a conflict situation; the availability of reflexive abilities and skills to determine the conflict causes).

Among the qualitative characteristics of the levels of this phenomenon traditionally high, satisfactory, and low levels are determined.

Researching the training of future foreign language teachers for the formation of tolerance, A. Logvinenko determines four interrelated components in the structure of readiness (axiological, cognitive, interactive, affective), considering the criteria and indicators: value (availability of value orientations in professional activity, understanding of cultural-national characteristics of different people, orientation to pedagogical activity on the basis of tolerance), content (awareness of the nature of tolerance, features of interaction in the situation of "dialogues of cultures", mechanisms of tolerant behaviour), activity (the ability to organize interpersonal tolerance interaction, non-verbal communication, conflict prevention), personal (the presence of communicative tolerance, empathy, emotional intelligence) [3, p. 16].

The justification of the pedagogical principles of tolerance and the main components of its formation (motivational, substantive, target, technological, controlling and regulating) are given in the works of teachers (R. Burns, I. Bech, V. Bibler, L. Vishnevsk, V. Ishchenko, I. Krivoshapka, V. Lectorovsky, O. Savchenko, etc.).

Taking into account the mentioned above, we determine the structure of readiness of the future primary school teacher for tolerant education of students as a fourcomponent one, we single out the following components: the conceptual-value component, needs-motivational, cognitive-practical, behavioral-reflexive.

Conceptually-value component of the primary school teacher's readiness for tolerant education of students has a priority when organizing the educational process in primary school. The dominant qualities of the individual, which ensure the implementation of the above component, should be considered as the teacher's ability to recognize the identity and uniqueness of the student, the belief in its inexhaustible abilities, openness to the perception of personality values, tolerance for the thoughts and behaviour of each student, orientation on partnership and cooperation.

The need-motivational component manifests itself in the nature of its attitude to the participants in the educational process (students, their parents, colleagues, etc.), which is possible provided that the educators feature benevolence, courtesy, sincerity, loyalty, restraint, mercy, empathy, justice, tolerance. 
The cognitive-practical component (component) of the primary school teachers readiness to tolerate students education is characterized by understanding the behaviour of the junior schoolchildren in society; the ability to forgive the mistakes; tolerant attitude to professional discomfort; the ability to compromise, to resolve the pedagogical situations that arise during the organization of the educational process in the primary school without any conflicts.

Behavioral-reflexive component involves the formation of the ability to adequately assess the existing pedagogical situation and identify it, flexibly respond to any changes in it, conduct self-examination, self-evaluation, self-control of behavior from the standpoint of humanistic pedagogy and, if necessary, to make timely corrections in the process of tolerance formation of primary school students.

Consequently, based on the results of the analysis of scientific research in the field of psychology, pedagogy, we came to the conclusion that the primary school teacher readiness to tolerate the education of students is a complex characteristic of a primary school teacher, a component of professional competence, which, in addition to the general human qualities that outline it, includes such a professionally important components as tolerant participation in the educational process, tolerant relationships with all its participants (students, colleagues, parents), their own tolerant position in the society and its cultivation in pupils.

In the integral sense, the readiness of a primary school teacher to tolerate the upbringing of students is a structure that involves the unity of components (tolerant consciousness, tolerant feelings, emotional stability, tolerant behavior, critical evaluation of their own actions, etc.); the formation of these components indicates the willingness of students - future teachers of primary school to tolerate the upbringing of students.

\section{References:}

1. Budnyk O.B. (2015). Teoretychni ta metodychni zasady profesiynoyi pidhotovky maybutnikh uchyteliv pochatkovykh klasiv do sotsial'no-pedahohichnoyi diyal'nosti [Theoretical and methodical principles of professional training of future primary school teachers for social and pedagogical activity] (PhD Thesis), Zhytomyr.

2. Kondrashova L.V. (2006). Kontseptsiya "Vzayemodiyi moral'nykh i psykholohichnykh yakostey u zmisti pedahohichnoho profesionalizmu" [The concept of interaction of moral and psychological qualities in the content of pedagogical professionalism]. Kryvyi Rig.

3. Lohvynenko A.Y. (2017). Pidhotovka maybutnikh uchyteliv inozemnoyi movy do formuvannya tolerantnosti $\mathrm{v}$ uchniv osnovnoyi shkoly [Training of future English teachers for tolerant education of secondary school students] (PhD Thesis) Odesa.

4. Rozum K.V. (2015). Formuvannya hotovnosti maybutnikh uchyteliv humanitarnoho profilyu do zapobihannya i rozv'yazannya konfliktiv u navchal'no-vykhovniy roboti z uchnyamy [Formation of future teachers readiness of the humanitarian direction to prevent and resolve conflicts in educational process with pupils]. Odesa.

5. Shcherbak I.V. Pidhotovka maybutn'oho vchytelya do hromadyans'koho vykhovannya molodshykh shkolyariv: suchasni pidkhody do problemy [Training a Future Teacher for Civic Education of Younger Schoolchildren: Modern Approaches to the Problem]. The scientific journal of MDU named after V.O. Sukhomlynskyi, vol. 1.30, pp. 98-105. Retrieved from: http://mdu.edu.ua/ wp-content/uploads/files/14_6.pdf 